\title{
Comparison of methods for calculating biological wastewater treatment
}

\author{
Elena Gogina*, and Olga Ogneva \\ Moscow State University of Civil Engineering, Yaroslavskoe shosse, 26, Moscow, 129337, Russia
}

\begin{abstract}
Due to the increase in the discharge of nitrogen and phosphorus compounds into water bodies in many countries, the problem of eutrophication has become the most relevant in the field of biological treatment technologies. To solve this problem, many technological schemes for purification from biogenic elements have been developed, based on different methods. The concept of biological purification, the composition and process of nutrition of heterotrophic microorganisms, as well as the course of the process of methanogenesis are analyzed. The analysis of the methods of the two countries, Russia and Germany. Most of the facilities in Russia are designed in accordance with SNiP 2.04.03.85, while Germany offers a different biological treatment method developed by the German Water Association DWA A131.
\end{abstract}

\section{Introduction}

Biological wastewater treatment is one of the main environmental problems both in our country and around the world. Since freshwater is a non-renewable resource, many countries are developing the most efficient wastewater treatment method. Each of the techniques has its own characteristics. In this article, I will consider two different methods of biological treatment: the first is the conservative calculation method in Russia, the second is the calculation method in Germany, since the country chosen for the analysis is advanced in the issue of biological treatment technologies. It should also be borne in mind that the biological treatment method cannot be universal for all countries, since decisions are made depending on the specifics of the economic activity of a particular object, the nature of the soil, the relief, the required degree of wastewater treatment, as well as the climatic conditions of the natural zone where the considered wastewater treatment facility is located. All these conditions can influence the choice of the biological treatment method and the composition of treatment facilities.

First of all, biological treatment is a set of measures aimed at removing contaminants contained in household, industrial and atmospheric wastewater for release into a reservoir. The biological treatment stage is the main one, as it involves the treatment of wastewater from organic pollutants such as BOD and COD and biogenic pollutants such as nitrogen and phosphorus [1]. The cleaning process is based on the vital activity of heterotrophic microorganisms, which are commonly called activated sludge or biofilm. These microorganisms function due to their ability to consume organic and inorganic compounds

\footnotetext{
${ }^{*}$ Corresponding author: goginaes@mgsu.ru
} 
as a source of energy and growth. And the ability of these microorganisms to form so-called colonies and accumulations makes it possible to easily separate them from purified water. The source of nutrition for activated sludge is proteins, fats and carbohydrates, which in turn are broken down to simple substances - water, methane, hydrogen sulfide and carbon dioxide [2].

An active process of breaking down organic substances, bacteria needs conditions such as the presence or absence of oxygen, maintaining a comfortable temperature of the environment and acid-base balance. A complete biological treatment requires two types of bacteria: aerobic and anaerobic. Oxygen is necessary for the vital activity of aerobic bacteria. Such microorganisms live at a temperature of $+9 \ldots+26^{\circ} \mathrm{C}$ and a $\mathrm{pH}$ of 5.0-7.0. For the vital activity of anaerobic bacteria, the absence of oxygen and a temperature of $+9 \ldots+37^{\circ}$ $\mathrm{C}$ and a $\mathrm{pH}$ of 6.0-8.0 are necessary [3].

Aerobic bacteria include pseudomonads, nitrifying bacteria, sulfur bacteria and thionic bacteria, filamentous and cellulose-decomposing bacteria. Pseudomonas make up about $80 \%$ of activated sludge. They recycle alcohols, fatty acids and other organic substances. The purpose of nitrifying bacteria is to oxidize the nitrogen compound. Sulfur bacteria and thionic bacteria recycle reduced sulfur compounds. Filamentous - oxidizes carbon compounds. Cellulose Decomposers - process cellulose fiber.

Anaerobic bacteria include hydrolytics, acidogenic, heteroacetogenic, and methanogenic bacteria. Hydrolytics are responsible for the first stage of methanogenesis. Bacteria break down proteins, fats, cellulose compounds, starch, and have ammonifying activity. As a result of their vital activity, glycerin, fatty acids, amino acids, peptides, mono- and disaccharides are formed. The acytogenic bacteria are responsible for the second stage of methanogenesis. With the help of bacteria, butyric acid, acetone-butyl, propionic, alcoholic fermentation occurs [4]. In the process of life, intermediate products of hydrolysis are processed. Heteroacetogenic bacteria are responsible for the third stage of methanogenesis. Microorganisms form biogas by processing hydrogen, carbon dioxide, acetate, methylamine and methanol. Methanogenesis is an important part of biological treatment for biogas production.

At the moment, from a technical point of view, there are two main options for biological treatment facilities: aerotanks and biofilters [5]. In the process of biological treatment in the aeration tank, the activated sludge and waste liquid move along the corridor of the aeration tank. As it moves, the following processes occur: the destruction and transformation of organic pollution by microorganisms and the bio sorption of pollution with the formation of activated sludge. Both organic and mineral contaminants are sorbed.

A biofilter is a rectangular or circular tank filled with filter material. The advantage of the biofilter is the ability to quickly install it in wastewater treatment plants. The mechanism of wastewater treatment from organic pollutants is carried out by the interaction of wastewater with active biomass, which is presented in the form of a biological film. The disadvantage of biofilters is the high cost of highly porous nozzles, the restriction on suspensions in drains and the need for periodic labor-intensive flushing of biofilters. The choice of structures depends on several climatic, geographical, economic and design conditions.

Based on the calculations, an appropriate set of facilities should be selected that is suitable for the most effective biological treatment. In the process of comparing the two techniques, we will identify the advantages and disadvantages of each of them. 


\section{Methods}

In Russia at the moment, the most widespread, scientifically grounded and repeatedly tested method for calculating aeration tanks is based on Set of rules and standards 2.04.03-85 [6]. The developed technology of wastewater purification from organic pollutants and nitrogen compounds is protected by RF patents No. 2210549 and 2351551. In the process of selecting and calculating the structure, it is necessary to carry out four parallel processes - oxidation of organic substances, oxidation of ammonium nitrogen to nitrites and nitrates, reduction of nitrites and nitrates to molecular nitrogen due to the oxidation of organic matter, the absorption of orthophosphates, the transformation of the latter into polyphosphates and their accumulation in the cells of activated sludge.

In Russia, stricter regulations on wastewater discharge relative to biogenic elements were introduced in the late 90s. These requirements have been in effect since June 2000 [7].

To start calculating the aeration tank, it is necessary to know the parameters of the treatment plant and the required degree of wastewater treatment before being released into the reservoir. Having this data, we can choose the method and technological scheme of cleaning. To accurately determine the parameters of the aeration tank, we need data on the mass load of the pollutant, the wastewater consumption and the concentration of pollutants in the wastewater [8]. Along with the calculated indicators, we need to determine the OS performance in terms of incoming organic pollution.

The layout of facilities on the territory of treatment facilities should be made taking into account the possible expansion prospects. It is also necessary to optimally use the slope of the terrain to allow the flow of wastewater through the treatment plant by gravity.

If a high concentration of organic pollutants is found in the wastewater, as well as a high concentration of sulfates, it is necessary to use aerobic and anaerobic biological treatment facilities. Additional nitrogen removal should be provided by biological nitri-denitrification. Phosphorus removal is carried out in several ways - improved biological phosphorus removal, removal with iron and aluminum salts, and bio-reagent removal. The chemical method of phosphorus removal is allowed to be used only for structures with a load of less than 50 thousand [9].

As initial parameters for calculating biological treatment processes with the removal of nitrogen (or nitrogen and phosphorus), it is allowed to use the values of the average load for BOD5, suspended solids, total nitrogen and total phosphorus for two weeks of the cold period of the year, characterized by the maximum BOD load for three years of observations.

The capacity of aeration tanks must be determined by the hourly average water inflow during the aeration period during the hours of maximum inflow. Next, it is necessary to calculate the aeration period $t_{\text {amt }}$ (aeration tank-mixer) or $t_{\text {atv }}$ (aerotank-displacer) and the degree of activated sludge recirculation $\mathrm{R}_{\mathrm{i}}$, taking into account the sludge dose ai and the sludge index Ji [10]. The sludge index is determined by diluting the sludge mixture to $1 \mathrm{~g} / 1$, depending on the load on the sludge[11]. After determining the number of sections, the working depth and the ratio of the width to the working depth of the aeration tanks and regenerators, it is necessary to determine the number of aerators and their depth. For this, we need to calculate the specific air flow $\mathrm{q}_{\text {air }}$ and the aeration intensity $\mathrm{J}_{\mathrm{a}}$.

In Germany, the most common method for calculating an aeration tank for nutrient removal was developed by the German Water Association DWA, Worksheet A 131 [12]. In this country, the requirements for maximum permissible concentration of contaminants at the discharge are set depending on the size of the treatment plant. The larger the treatment facility, the greater its impact on the environment, the more stringent the requirements for it.

To intensify the operation of biological treatment facilities, a method is often used to increase the dose of sludge and, accordingly, increase its oxidizing power. The age of the sludge is its average residence time in biological treatment facilities. An increase in the mass of activated sludge occurs due to the consumption of contaminated organic matter by the 
sludge. It has been experimentally established that the mass of the sludge growth includes $20-30 \%$ of the BOD full removed in the structure and $70-80 \%$ of the suspended solids supplied to it. If the growing part of the sludge is not removed from the system in a timely manner, the quality of treatment will deteriorate. The higher the increase in sludge, the greater the amount of excess sludge, the faster it is renewed. Accordingly, the age of the silt is less. The longer the time that the sludge is in the aeration tank, the more sludge that has undergone self-oxidation in it. This sludge has a low metabolic activity. On the contrary, too young sludge also has a low metabolic activity. Under the conditions under which the sludge is 2-5 days old, optimal metabolic activity is ensured. In Germany, when calculating the age of the sludge, temperature, the growth rate of nitrifiers and the safety factor are taken into account [13].

The calculation of aeration tanks is based on the determination of the minimum aerobic age of activated sludge, necessary for the preservation and accumulation of nitrifying bacteria in it. After that, the ratio of the volume of the denitrification zone to the total volume is set. For German wastewater treatment plants, this ratio is usually 0.3 [14]. This is followed by the calculation of the total age of the activated sludge. After calculating the required amount of oxygen, the calculation of the growth of activated sludge and the incorporation of nitrogen in it follows. When compiling the nitrogen balance, the amount of nitrate formed during the nitrification process is also determined. If the ratio of the amount of nitrate to the amount of organic matter is not equal to that required for the denitrification process, a different volume ratio should be chosen. In the positive case, the load on the sludge and the total volume of the aeration tank are determined.

In Germany, as in other EU countries, maximum permissible concentrations of nutrients in treated wastewater are established, depending on the size of the treatment plant. For wastewater treatment plants designed for less than 100,000 and more than 100,000 equivalent residents, the concentration of total nitrogen should not exceed $15 \mathrm{mg} / 1$ and $10 \mathrm{mg} / 1$, respectively, the concentration of phosphorus $-2 \mathrm{mg} / 1$ and $1 \mathrm{mg} / 1$, respectively.

The formation of rather high average concentrations of municipal wastewater is explained by the prevalence of separate municipal and rainwater sewer networks. It should be noted that the temperature of waste water in winter does not fall below $10^{\circ} \mathrm{C}$ (Table 1$)$.

Table 1. Average concentration of wastewater in Germany [8]

\begin{tabular}{|c|c|c|c|c|c|c|}
\hline Parameter & $\begin{array}{c}\mathrm{COD}, \\
\mathrm{mg} / \mathrm{l}\end{array}$ & $\begin{array}{c}\mathrm{BOD}, \\
\mathrm{mg} / \mathrm{l}\end{array}$ & $\mathrm{Wt}, \mathrm{mg} / \mathrm{l}$ & $\begin{array}{c}\mathrm{N}_{\text {tot, }} \\
\mathrm{mg} / \mathrm{l}\end{array}$ & $\begin{array}{c}\mathrm{P}_{\text {tot, }} \\
\mathrm{mg} / \mathrm{l}\end{array}$ & $\begin{array}{c}\mathrm{T}_{\text {win, }} \\
{ }^{\circ} \mathrm{C}\end{array}$ \\
\hline Concentration & 548 & 319 & 208 & 59 & 8 & $>10$ \\
\hline
\end{tabular}

Analyzing the data in Table 2, we can notice that the minimum age of activated sludge in Germany is less than in Russia. Since the growth of nitrifiers depends on temperature, the critical winter temperature of wastewater is taken as the design temperature in all of the countries listed.

Table 2. Minimum age of aerobic activated sludge (days) [7]

\begin{tabular}{|c|c|c|}
\hline $\mathrm{T} \mathrm{C}^{\mathrm{o}}$ & DWA & СНиП \\
\hline 5 & 18,31 & 40,67 \\
\hline 10 & 9,99 & 18,88 \\
\hline 15 & 6,12 & 9,60 \\
\hline 20 & 3,75 & 6,45 \\
\hline 25 & 2,30 & 5,30 \\
\hline 30 & 1,41 & 4,71 \\
\hline
\end{tabular}




\section{Conclusions}

Comparing the calculation methods in Russia and in Germany, you can see that the calculation principle in both countries is largely the same. To calculate treatment facilities in Russia, a calculation method is required that is applicable to all regions of the country and takes into account the characteristics of the composition and temperature of wastewater in six climatic zones: from subtropical to polar. The requirements for maximum permissible concentrations for discharge into water bodies in Russia are not the same. Difference does not depend on the climate zone, but depends on the type of watercourse receiving treated wastewater [15]. Therefore, it is necessary to ensure the flow of nitrification processes throughout the year at many wastewater treatment plants in Russia with the discharge of wastewater into reservoirs of high categories [16]. Today, designers and technologists are engaged in the design of treatment facilities located in the same climatic zones in which the method was developed.

Methods of biological treatment, as can be seen, have a number of advantages: the time of water purification is reduced, the waste products of wastewater -carbon dioxide, water, methane-return to nature. Excess silt serves as a good fertilizer. Low cost, since no additional reagents or devices are needed for the biological purification process. Savings are also made by reducing staff.

Biological water purification was invented by nature itself. However, the development of our civilization requires the acceleration of natural processes. In this case, artificial human intervention in the biological cleaning mechanism is beneficial to nature. Therefore, it is important to understand which of the many methods will most effectively cope with the tasks set, and whether we have the opportunity to adjust the conservative Russian methodology based on the experience of other countries, in particular Germany.

\section{References}

1. Ilyushina V. V. Modern methods of wastewater treatment. Sovremennaya tekhnika $i$ tekhnologii, 2017. № 2 [Электронный pecypc]. URL: https://technology.snauka.ru/2017/02/12446 (дата обращения: 29.02.2021).

2. Y.V. Voronov, S.V. Yakovlev, Water disposal and wastewater treatment, Textbook for universities, Publishing house of the Association of Building Universities (2006)

3. Dolivo-Dobrovolsky, L. B. Microbiological processes

of water purification: a textbook / L. B. Dolivo-Dobrovolsky. - M.: Publishing House Municipal services of the RSFSR, 1958. - 174 p.I.P.

4. Korshunova, T. Yu. Microbiological processes at treatment

facilities / T. Yu. Korshunova, N. N. Silishchev, O. N. Loginov. - Ufa :

Publishing house "Reactiv", 2005. - 62 p.

5. Mukhlenov, A.Y. Averbukh, D.A. Kuznetsov, General chemical technology, Textbook, 2 (1984)

6. S.P Maksimov, I. A. Alekseev, Overview of biological methods of sewage refining

7. Set of rules and standards 2.04.03-85. Sewerage. External networks and facilities (1985)

8. V. I. Kalitsun, V. N. Nikolaev,V. D. Zhuravlev, M. G. Kartavtseva, Modern methods of intensifying the work of aeration tanks at the treatment facilities of large cities: overview information. - 1985. - Issue 6. - 24 p.

9. SanPiN 2.1.5.980-00. Hygienic requirements for the protection of surface waters (2000) 
10. SP 32.13330.2012 Sewerage. External networks and facilities. Updated edition of SNiP 2.04.03-85 (2012)

11. Karyukhina, T. A. Water chemistry and microbiology: textbook for technical schools / T. A. Karyukhina, I. N. Churbanova. - 3rd ed., reprint. and add. - M.: Publishing house "Stroyizdat", 1995 - - 208 p.

12. DWA-131. Bemessung von einstufigen Belebungsanlagen, Deutschland, Hennef Mai (2000)

13. Verordnung ueber Anforderungen an das Einleiten von Abwasser in Gewaesser AbwV - Abwasserverordnung, vom 17. Juni 2004, Deutschland. 5. EPA - Design Manuel for Nitrogen Control. U.S. Environmental Protection Agency, Lancaster, Pensylvania, 1993.

14. H. Scheer, Bemessung von Kläranlagen auf Stickstoff- und Phosphorelimination im internationalen Vergleich

15. M. Hentse, Waste water treatment. Biological and chemical processes, Mir (2004)

16. V. N. Shvetsov, K. M. Morozova, K. V. Domnin, E. E. Arkhipova, Water supply and sanitary engineering, 7, 53 (2012) 